\title{
Monitoring of drug resistance amplification and attenuation with the use of tetracycline-resistant bacteria during wastewater treatment
}

\author{
Monika Harnisz ${ }^{1, *}$ Ewa Korzeniewska $^{1}$, Sebastian Niestępski ${ }^{1}$, Adriana Osińska ${ }^{1}$, and \\ Beata Nalepa ${ }^{2}$ \\ ${ }^{1}$ Department of Environmental Microbiology, University of Warmia and Mazury in Olsztyn, \\ ul. Prawocheńskiego 1, 10-957 Olsztyn, Poland \\ ${ }^{2}$ Department of Food and Industrial Microbiology, University of Warmia and Mazury, Plac \\ Cieszyński 1, 10-726 Olsztyn, Poland
}

\begin{abstract}
The objective of this study was to monitor changes (amplification or attenuation) in antibiotic resistance during wastewater treatment based on the ecology of tetracycline-resistant bacteria. The untreated and treated wastewater were collected in four seasons. Number of tetracycline- $\left(\mathrm{TET}^{\mathrm{R}}\right)$ and oxytetracycline-resistant $\left(\mathrm{OTC}^{\mathrm{R}}\right)$ bacteria, their qualitative composition, minimum inhibitory concentrations (MICs), sensitivity to other antibiotics, and the presence of $\operatorname{tet}(\mathrm{A}, \mathrm{B}, \mathrm{C}, \mathrm{D}, \mathrm{E})$ resistance genes were determined. TET $^{\mathrm{R}}$ and $\mathrm{OTC}^{\mathrm{R}}$ counts in untreated wastewater were 100 to 1000 higher than in treated effluent. OTC $^{\mathrm{R}}$ bacterial counts were higher than $\mathrm{TET}^{\mathrm{R}}$ populations in both untreated and treated wastewater. TET $^{\mathrm{R}}$ isolates were not dominated by a single bacterial genus or species, whereas Aeromonas hydrophila and Aeromonas sobria were the most common in $\mathrm{OTC}^{\mathrm{R}}$ isolates. The treatment process attenuated the drug resistance of $\mathrm{TET}^{\mathrm{R}}$ bacteria and amplified the resistance of $\mathrm{OTC}^{\mathrm{R}}$ bacteria. In both microbial groups, the frequency of tet(A) gene increased in effluent in comparison with untreated wastewater. Our results also indicate that treated wastewater is a reservoir of multiple drug-resistant bacteria as well as resistance determinants which may pose a health hazard for humans and animals when released to the natural environment.
\end{abstract}

\section{Introduction}

Microbial resistance to drugs poses a growing threat for human health and life. The widespread use of antibiotics in the treatment of bacterial diseases has contributed to the development of strains that are resistant to this group of drugs. The problem has been escalating dramatically by the increased use of antimicrobial agents in medicine, detergent production, agriculture, breeding and cosmetic industry [1-3]. Multiple drug resistance has developed and spread rapidly among various bacterial groups within a short timeline of

\footnotetext{
* Corresponding author: monika.harnisz@uwm.edu.pl
} 
evolution. The problem is deepened by the existence of large bacterial populations, short generation times and effective mechanisms of genetic information exchange [4].

Wastewater treatment plants (WWTPs) are flagship projects aiming to prevent environmental pollution. Wastewater purified of suspended matter, excess organic substances and biogenic elements can be reused to irrigate fields or evacuated to surface waters [6,7]. Municipal treatment plants are supplied with wastewater generated by households, hospitals, public utility buildings, industrial plants as well as rain water. This combination of organic substances, biogenic elements and trace amounts of antibiotics supports the development and survival of drug-resistant bacteria [8]. The use of activated sludge and biological membrane systems in the treatment process contributes to the exchange of genetic information between bacteria of the same or different species, including microorganisms from unrelated families [9]. The above facilitates the exchange of genes located on mobile plasmids, including those encoding drug resistance [10].

WWTPs are important reservoirs of antibiotic resistance of both commensal and pathogenic organisms [11, 12]. Drug-resistant bacteria and resistance genes can be released from the plant into the natural environment. To mitigate this threat, the presence of antibiotic-resistant bacteria has to be determined in untreated and treated wastewater. The resulting data support an evaluation of the effect of the treatment process on changes in bacterial resistance to antibiotics.

The microbial indicator has been defined by Nielsen et al. [13] as "microbial parameter that represents properties of the environment or impacts to the environment, which can be interpreted beyond the information that the measured or observed parameter represents itself'. Microbial bioindicators could be based on functional or structural diversity of the community [14]. In the case of changes in the antibiotic resistance of bacteria, structural bioindicators are specific bacterial species and genera which are cultured on selective media and functional bioindicators comprise groups of bacteria resistant to a specific drug or a class of drugs. They are grown on nutrient agars, such as TSA, with the addition of antibiotics, such as tetracyclines which, despite a rapid increase in bacterial resistance, continue to be widely used in human and veterinary medicine.

The objective of this study was to monitor changes (amplification or attenuation) in antibiotic resistance during wastewater treatment based on the ecology of tetracycline- and oxyteracycline-resistant bacteria in untreated and treated wastewater. In Poland, tetracycline is one of the most popular drug of choice in human medicine, whereas oxytetracycline is widely used in the treatment of both humans and animals. Akinbowale et al. [15] noticed, that minimum inhibitory concentrations of these two drugs can be different, so we thought the populations of tetracycline- and oxytetracycline-resistant bacteria can be different, also. Therefore, we decided to study both microbial groups.

\section{Materials and Methods}

\subsection{Wastewater treatment plant}

The investigated site was the Łyna Municipal Waste Treatment Plant in Olsztyn. The plant's process line comprises mechanical, biological and chemical treatment sections, as well as sludge processing units. The plant has the following technical specification: treatment system - activated sludge, average processing capacity $-60,000 \mathrm{~m}^{3} / \mathrm{d}$, wastewater type - municipal wastewater, mechanical treatment devices - screenings, grit chamber and pre-sedimentation tank, biological treatment devices - separation chambers, aeration chambers and secondary sedimentation tanks, sedimentation devices - closed and open digestion chambers, belt filter press, incinerator. 


\subsection{Sample collection}

The experimental material comprised samples of untreated (from grid chamber) and treated (effluent of secondary sedimentation tank) wastewater collected on four occasions: in April, July and October 2012 and in February 2013. Wastewater samples were collected into sterile bottles, transported to the laboratory at a temperature of $4{ }^{\circ} \mathrm{C}$ and processed on the day of collection.

\subsection{Heterotrophic plate counts and counts of tetracycline- and oxytetracycline-resistant bacteria}

Heterotrophic plate counts (HPC), counts of tetracycline-resistant bacteria (TET ${ }^{\mathrm{R}}$ ) and counts of oxytetracycline-resistant bacteria were determined in plates containing the TSA medium (Oxoid) without/with tetracycline and oxytetracycline supplementation, respectively. The plates were cultured at a temperature of $30^{\circ} \mathrm{C}$ for $24 \mathrm{~h}$. According to CLSI guidelines [16], pathogens with MIC values of the tested antibiotics at $\geq 16 \mu \mathrm{g} / \mathrm{mL}$ are regarded as resistant. In this study, tetracycline and oxytetracycline were applied at a concentration of $32 \mu \mathrm{g} / \mathrm{mL}$ to isolate highly resistant bacteria. MIC value of these antibiotics were determined by the agar dilution method with final antibiotic concentrations in the range of 32 to $512 \mu \mathrm{g} / \mathrm{mL}$. Cultured colonies of HPC, TET $^{\mathrm{R}}$ and $\mathrm{OTC}^{\mathrm{R}}$ were counted, and the results were stated in terms of colony forming units (CFU) per $\mathrm{mL}$ of wastewater. Colonies with various phenotypes were isolated from the TSA medium supplemented with tetracycline and oxytetracycline. A total of 40 isolates were obtained from each medium (in summary 80 isolates). The strains were stored on the LB medium (Merck) with $10 \%$ glycerol at $-70^{\circ} \mathrm{C}$ for further analyses.

\subsection{Antibiotic susceptibility testing}

$\mathrm{TET}^{\mathrm{R}}$ and $\mathrm{OTC}^{\mathrm{R}}$ strains isolated in the study were subjected to sensitivity tests against nine antimicrobials from five classes: (1) beta-lactams: mezlocillin (MEZ $75 \mu \mathrm{g}$ ), ampicillin (AMP $10 \mu \mathrm{g}$ ), piperacillin (PRL $75 \mu \mathrm{g}$ ); amoxicillin/clavulanic acid (AMC 20/10 $\mu \mathrm{g}$ ), ceftazidime (CAZ $30 \mu \mathrm{g}$ ), cefotaxime (CTX $30 \mu \mathrm{g}$ ); (2) aminoglycosides: gentamicin (CN $10 \mu \mathrm{g}$ ), tobramycin (TOB $10 \mu \mathrm{g}$ ); (3) macrolides: erythromycin (TOB $10 \mu \mathrm{g}$ ); (2) tetracyclines: tigecycline (TGC $15 \mu \mathrm{g}$ ); (4) trimethoprim/sulfamethoxazole (SXT 1.25/23.75 $\mu \mathrm{g}$ ); (6) phenicols: chloramphenicol (C $30 \mu \mathrm{g}$ ); and (6) fluoroquinolones: ciprofloxacin (CIP $30 \mu \mathrm{g}$ ). All disks were supplied by Oxoid. Resistance was estimated by measuring the inhibition zone according to the guidelines of CLSI [16].

\subsection{Identification of isolates and multiplex PCR of tetracycline-resistant genes}

Genomic DNA was isolated by the use of thermal lysis [14]. TET $^{\mathrm{R}}$ and $\mathrm{OTC}^{\mathrm{R}}$ isolates were identified by $16 \mathrm{~S}$ rRNA gene sequencing in accordance with a previously described method [14].

The mechanism of molecular resistance to tetracyclines was analyzed with the use of five out of around 40 known determinants [17]. They were selected based on source data indicating that tet(A), (B), (C), (D) and (E) genes are the most popular determinants of resistance in Enterobacteriaceae and Aeromonas sp. bacteria [18, 19]. Multiplex PCR was conducted in line with the methodology proposed by Nawaz et al. [18]. For all reactions, standard PCR mixtures without DNA template were used as negative controls. Plasmids 
carrying tet genes or the $16 \mathrm{~S}$ rRNA gene verified by sequencing were used as positive controls.

\subsection{Data analyses}

One way analysis of variance (ANOVA, StatSoft Inc., 1984-2017) was used to check differences in the abundance of the studied bacterial groups between the analyzed sites.

\section{Results}

HPC analyses revealed differences in the size of $\mathrm{TET}^{\mathrm{R}}$ and $\mathrm{OTC}^{\mathrm{R}}$ bacterial populations, subject to the site and time of sampling. $\mathrm{TET}^{\mathrm{R}}$ and $\mathrm{OTC}^{\mathrm{R}}$ concentrations in untreated wastewater were 100 to 1000 -fold higher than in discharged effluent $(p=0.006$ and $\mathrm{p}=0.003$ for $\mathrm{TET}^{\mathrm{R}}$ and $\mathrm{OTC}^{\mathrm{R}}$, respectively) (Table 1 ).

Table 1.The share of tetracycline- and oxytetracycline-resistant strains incubated at a temperature of $30^{\circ} \mathrm{C}\left(\mathrm{TET}^{\mathrm{R}} 30^{\circ} \mathrm{C}\right.$ and $\left.\mathrm{OTC}^{\mathrm{R}} 30^{\circ} \mathrm{C}\right)$ in total heterotrophic bacterial counts incubated under identical conditions $\left(\mathrm{HPC} 30^{\circ} \mathrm{C}\right)$.

\begin{tabular}{|c|c|c|c|c|}
\hline \multirow{2}{*}{\multicolumn{2}{|c|}{ Bacterial group }} & \multirow{3}{*}{$\frac{\text { Date }}{04.2012}$} & \multicolumn{2}{|c|}{ Sampling site } \\
\hline & & & \multirow{2}{*}{$\begin{array}{c}\begin{array}{c}\text { Untreated } \\
\text { wastewater }\end{array} \\
6.18 \times 10^{4}\end{array}$} & \multirow{2}{*}{$\begin{array}{c}\begin{array}{c}\text { Treated } \\
\text { wastewater }\end{array} \\
8.40 \times 10^{2}\end{array}$} \\
\hline \multirow{4}{*}{$\mathrm{TET}^{\mathrm{R}} 30^{\circ} \mathrm{C}^{1)}$} & \multirow{12}{*}{$\mathrm{CFU} / \mathrm{cm}^{3}$} & & & \\
\hline & & 07.2012 & $1.08 \times 10^{5}$ & $1.26 \times 10^{3}$ \\
\hline & & 10.2012 & $1.15 \times 10^{5}$ & $3.80 \times 10^{2}$ \\
\hline & & 02.2013 & $3.36 \times 10^{4}$ & $7.02 \times 10^{2}$ \\
\hline & & 04.2012 & $3.51 \times 10^{5}$ & $6.61 \times 10^{2}$ \\
\hline$O^{R} C^{R} 30^{\circ} C^{2)}$ & & 07.2012 & $1.23 \times 10^{5}$ & $1.52 \times 10^{3}$ \\
\hline OIC & & 10.2012 & $1.99 \times 10^{5}$ & $1.86 \times 10^{3}$ \\
\hline & & 02.2013 & $2.74 \times 10^{5}$ & $6.50 \times 10^{3}$ \\
\hline \multirow{4}{*}{$\mathrm{HPC} 30^{\circ} \mathrm{C}^{3)}$} & & 04.2012 & $5.01 \times 10^{6}$ & $3.67 \times 10^{4}$ \\
\hline & & 07.2012 & $9.70 \times 10^{6}$ & $7.40 \times 10^{4}$ \\
\hline & & 10.2012 & $9.60 \times 10^{6}$ & $2.05 \times 10^{4}$ \\
\hline & & 02.2013 & $4.88 \times 10^{6}$ & $1.21 \times 10^{5}$ \\
\hline \multirow{4}{*}{$\begin{array}{l}\text { Share of TET }{ }^{\mathrm{R}} 30^{\circ} \mathrm{C} \\
\text { in HPC } 30^{\circ} \mathrm{C}\end{array}$} & \multirow{8}{*}{$\%$} & 04.2012 & 1.23 & 2.3 \\
\hline & & 07.2012 & 1.1 & 1.7 \\
\hline & & 10.2012 & 1.2 & 1.85 \\
\hline & & 02.2013 & 0.7 & 0.6 \\
\hline \multirow{4}{*}{$\begin{array}{c}\text { Share of OTC } 30^{\circ} \mathrm{C} \\
\text { in HPC } 30^{\circ} \mathrm{C}\end{array}$} & & 04.2012 & 7 & 1.8 \\
\hline & & 07.2012 & 1.3 & 2.1 \\
\hline & & 10.2012 & 2.1 & 9.1 \\
\hline & & 02.2013 & 5.6 & 5.4 \\
\hline
\end{tabular}

Maximum TET $^{\mathrm{R}}$ levels were noted in October and July 2012 in untreated and treated wastewater, respectively. The highest OTCR counts in inflows and outflows of WWTP were reported in April 2012 and February 2013. OTCR bacteria were more abundant than TETR bacteria in both untreated and treated wastewater samples $(p=0.012)$. In both incoming and outgoing wastewater, TETR had the lowest share of HPC in February 2013, and the highest - in April 2012. OTC ${ }^{\mathrm{R}}$ was characterized by a different share of HPC. The percentage share of OTC ${ }^{\mathrm{R}}$ bacteria in untreated sewage was the lowest in July 2012 and the 
highest in April 2012. As regards treated wastewater, the lowest and the highest percentages of OTC ${ }^{\mathrm{R}}$ bacteria were noted in April 2012 and October 2013, respectively.

In $\mathrm{TET}^{\mathrm{R}}$ bacteria, the predominance of a single genus or species was not observed. In the group of $40 \mathrm{OTC}^{\mathrm{R}}$ isolates, eight Aeromonas hydrophila, ten Aeromonas sobria, one Aeromonas jandei and two Aeromonas allosacharphila strains were identified and found to predominate (Table 2).

In the group of $\mathrm{TET}^{\mathrm{R}}$ bacteria isolated from untreated wastewater, Acinetobacter baumanii was characterized by very low sensitivity to drugs (MIC of TET - $256 \mu \mathrm{g} / \mathrm{mL}$, MIC of OTC $-512 \mu \mathrm{g} / \mathrm{mL}$, MDR to seven groups of drugs). The least drug-sensitive microorganism isolated from the $\mathrm{OTC}^{\mathrm{R}}$ group in untreated wastewater was Aeromonas sobria (MIC of TET $-32 \mu \mathrm{g} / \mathrm{mL}$, MIC of OTC $-256 \mu \mathrm{g} / \mathrm{mL}$, resistant to five classes of UW - untreated wastewater, TW - treated wastewater; MDR to: B - $\beta$-lactams, A-Aminoglycosides, M-Macrolides, T-Tetracyclines, S-Sufonamides/Trimethoprim, P-Phenicols, F-Fluoroquinolones; nd - not detected; - resistance to less than three classes of drugs antibiotics). The most frequently observed pattern of resistance was insensitive to $\beta$-lactams, aminoglycosides and macrolides (Table 2).

Table 2. Diversity of tetracycline- and oxytetracycline-resistant bacteria, minimum inhibitory concentrations of tetracycline (TET) and oxytetracycline (OTC), the resistance profile, multi-drug resistance (MDR) and determinants of resistance of strains isolated from UW and WW.

\begin{tabular}{|c|c|c|c|c|c|c|}
\hline Origin & & $\begin{array}{c}\text { Identification } \\
\text { results } \\
\text { (number of strains) }\end{array}$ & $\begin{array}{l}\text { MIC of } \\
\text { TET/OTC }\end{array}$ & $\begin{array}{l}\text { Resistance profile } \\
\text { (number of strains) }\end{array}$ & MDR & Genes \\
\hline \multirow{13}{*}{ UW } & \multirow{10}{*}{ TET $^{\mathrm{R}}$} & $\begin{array}{l}\text { Acinetobacter } \\
\text { baumanii(2) }\end{array}$ & $256 / 512$ & $\begin{array}{l}\text { MEZ, CAZ, CTX, CN, TOB, E,SXT,C,CIP(1) } \\
\text { AMP,AMC,PRL,CAZ,CTX,E,TGC,C(1) }\end{array}$ & $\begin{array}{l}\text { BAMTSPF } \\
\text { BMTP }\end{array}$ & $\operatorname{tet}(\mathrm{B})$ \\
\hline & & $\begin{array}{l}\text { Acinetobacter } \\
\text { junii(2) }\end{array}$ & $96 / 512$ & $\begin{array}{l}\text { MEZ,AMP,AMC,PRL,CAZ,CTX,E,TGC,C(1) } \\
\text { AMP,PRL,CAZ,CTX,E,TGC,C(1) }\end{array}$ & $\begin{array}{l}\text { BMTP } \\
\text { BMTP }\end{array}$ & $\begin{array}{l}\operatorname{tet}(\mathrm{A}), \operatorname{tet}(\mathrm{B}) \\
\operatorname{tet}(\mathrm{B})\end{array}$ \\
\hline & & $\begin{array}{l}\text { Burkholderia } \\
\text { cepacia(3) }\end{array}$ & $96 / 128$ & $\begin{array}{l}\text { AMP(1) } \\
\text { AMP,PRL,CAZ,CTX,E,TGC,C(1) } \\
\text { AMP,AMC,PRL,CAZ,CTX,E,TGC,C(1) }\end{array}$ & $\begin{array}{l}\text { ВMTP } \\
\text { BMTP }\end{array}$ & $\begin{array}{l}\operatorname{tet}(\mathrm{A}) \\
\operatorname{tet}(\mathrm{A}) \\
\operatorname{tet}(\mathrm{A})\end{array}$ \\
\hline & & $\begin{array}{l}\text { Klebsiella } \\
\text { pneumoniae(1) }\end{array}$ & $96 / 512$ & AMP,E,TGC(1) & BTP & $\operatorname{tet}(\mathrm{E})$ \\
\hline & & $\begin{array}{l}\text { Pasteurella } \\
\text { pneumotropica(1) }\end{array}$ & $32 / 128$ & MEZ,AMP,AMC,PRL,CAZ,CTX,E,TGC,C(1) & BMTP & nd \\
\hline & & $\begin{array}{l}\text { Plesiomonas } \\
\text { shigelloides(3) }\end{array}$ & $96 / 128$ & $\begin{array}{l}\text { MEZ,AMP,AMC,CAZ,CTX(1) } \\
\text { MEZ,AMP,AMC,PRL,CAZ,CTX,E,TGC,C(2) }\end{array}$ & BMTP & $\operatorname{tet}(\mathrm{E})$ \\
\hline & & $\begin{array}{l}\text { Pseudomonas } \\
\text { putida(1) }\end{array}$ & $64 / 128$ & MEZ,AMP,AMC,PRL,CAZ,CTX,E,TGC,C & BMTP & $\operatorname{tet}(\mathrm{D})$ \\
\hline & & $\begin{array}{l}\text { Salmonella } \\
\text { arizonae(3) }\end{array}$ & $128 / 512$ & $\begin{array}{l}\text { AMP,CTX(1) } \\
\text { MEZ,AMP,AMC,PRL,CAZ,CTX,E,TGC,C(1) } \\
\text { AMP,AMC,PRL,CAZ,CTX,E,TGC,C(1) }\end{array}$ & $\begin{array}{l}\text { BMTP } \\
\text { BMTP }\end{array}$ & $\begin{array}{l}\operatorname{tet}(\mathrm{D}) \\
\operatorname{tet}(\mathrm{D}) \\
\operatorname{tet}(\mathrm{D})\end{array}$ \\
\hline & & $\begin{array}{l}\text { Serratia } \\
\text { marcescens(3) }\end{array}$ & $128 / 512$ & $\begin{array}{l}\text { MEZ,AMP,AMC,CAZ,CTX,CIP(1) } \\
\text { MEZ,AMP,AMC,PRL,CAZ,CTX,E,TGC(1) } \\
\text { AMP,AMC,PRL,CAZ,CTX,E,TGC,C(1) }\end{array}$ & $\begin{array}{l}\text { BMT } \\
\text { BMTP }\end{array}$ & $\begin{array}{l}\operatorname{tet}(\mathrm{D}) \\
\operatorname{tet}(\mathrm{D}) \\
\operatorname{tet}(\mathrm{D})\end{array}$ \\
\hline & & \begin{tabular}{|l|} 
Sphingomonas \\
multivorum(1)
\end{tabular} & $64 / 512$ & AMP,PRL,CAZ,CTX,E,TGC,C(1) & ВМТР & nd \\
\hline & \multirow{3}{*}{$\mathrm{OTC}^{\mathrm{R}}$} & $\begin{array}{l}\text { Aeromonas } \\
\text { hydrophila(4) }\end{array}$ & $128 / 256$ & $\begin{array}{l}\text { AMP,E(2) } \\
\text { AMP,AMC,E(2) }\end{array}$ & - & $\begin{array}{l}\operatorname{tet}(A) \\
\operatorname{tet}(B)\end{array}$ \\
\hline & & $\begin{array}{l}\text { Aeromonas } \\
\text { sobria }(6)\end{array}$ & $\begin{array}{l}32 / 128 \\
32 / 256 \\
32 / 128 \\
32 / 128\end{array}$ & $\begin{array}{l}\text { AMP,E(1) } \\
\text { AMP,SXT,C,CIP(2) } \\
\text { AMP,CAZ,CTX,CN,TOB,E,SXT,C,CIP(2) } \\
\text { AMP,MEZ,CAZ,CTX,CN,TOB,E(1) }\end{array}$ & $\begin{array}{l}\text { BAMSP } \\
\text { BAM }\end{array}$ & $\begin{array}{l}\text { nd } \\
\operatorname{tet}(A), \operatorname{tet}(B) \\
\operatorname{tet}(A), \operatorname{tet}(B) \\
\text { nd }\end{array}$ \\
\hline & & Citrobacter & $128 / 128$ & MEZ,AMP,AMC,CAZ,CTX(1) & - & $\operatorname{tet}(A)$ \\
\hline
\end{tabular}




\begin{tabular}{|c|c|c|c|c|c|c|}
\hline & & freundii(2) & $96 / 128$ & MEZ,CAZ,CTX,CN,TOB,E(1) & BAM & $\operatorname{tet}(A)$ \\
\hline & & Escherichia coli(3) & $96 / 256$ & $\begin{array}{l}\text { MEZ,AMP,AMC,CAZ,CTX(1) } \\
\text { MEZ,CAZ,CTX,CN,TOB,E(2) }\end{array}$ & BAM & $\operatorname{tet}(A)$ \\
\hline & & $\begin{array}{l}\text { Pseudomonas } \\
\text { putida(1) }\end{array}$ & $96 / 128$ & SXT,C,CIP(1) & SPF & $\operatorname{tet}(A)$ \\
\hline & & $\begin{array}{l}\text { Sphingomonas } \\
\text { multivorum(2) }\end{array}$ & $32 / 128$ & $\begin{array}{l}\text { AMP,CTX(1) } \\
\text { MEZ,CAZ,CTX,CN,TOB,E(1) }\end{array}$ & BAM & $\operatorname{tet}(A)$ \\
\hline & & Yersinia pestis(2) & $32 / 128$ & $\begin{array}{l}\text { MEZ,AMP,AMC,CAZ,CTX(1) } \\
\text { MEZ,CAZ,CTX,CN,TOB,E(1) }\end{array}$ & BAM & $\begin{array}{l}\operatorname{tet}(E) \\
\operatorname{tet}(E)\end{array}$ \\
\hline \multirow{19}{*}{ TW } & \multirow{8}{*}{\begin{tabular}{|c|} 
\\
TET $^{\mathrm{R}}$ \\
\end{tabular}} & $\begin{array}{l}\text { Acinetobacter } \\
\text { baumanni(2) }\end{array}$ & $32 / 256$ & MEZ,AMP,PRL,E,CIP(2) & BMF & $\operatorname{tet}(\mathrm{A})$ \\
\hline & & $\begin{array}{l}\text { Acinetobacter } \\
\text { junii(2) }\end{array}$ & $32 / 512$ & $\begin{array}{l}\text { MEZ,AMP,PRL,E,CIP(1) } \\
\text { MEZ,AMP,PRL,E,SXT,CIP(1) }\end{array}$ & $\begin{array}{l}\text { BMF } \\
\text { BMF }\end{array}$ & $\mid \operatorname{tet}(\mathrm{A})$ \\
\hline & & $\begin{array}{l}\text { Klebsiella } \\
\text { pneumoniae(3) }\end{array}$ & $\begin{array}{c}32 / 256 \\
128 / 256\end{array}$ & $\begin{array}{l}\text { AMP,AMC(2) } \\
\text { MEZ,AMP,AMC,CAZ,CTX(1) }\end{array}$ & - & $\operatorname{tet}(\mathrm{E})$ \\
\hline & & $\begin{array}{l}\text { Pasteurella } \\
\text { pneumotropica(3) }\end{array}$ & $\begin{array}{l}32 / 256 \\
128 / 256\end{array}$ & $\begin{array}{l}\text { MEZ,AMP,PRL,E,SXT,CIP(2) } \\
\text { MEZ,AMP,AMC,CAZ,CTX(1) }\end{array}$ & BMSF & $\operatorname{tet}(\mathrm{A})$ \\
\hline & & $\begin{array}{l}\text { Pseudomonas } \\
\text { putida(3) }\end{array}$ & $\begin{array}{c}32 / 512 \\
32 / 512 \\
128 / 512 \\
\end{array}$ & $\begin{array}{l}\text { AMP,E(1) } \\
\text { CTX,E(1) } \\
\text { MEZ,AMP,PRL,E(1) }\end{array}$ & - & $\begin{array}{l}\operatorname{tet}(\mathrm{A}) \\
\operatorname{tet}(\mathrm{A}) \\
\operatorname{tet}(\mathrm{A})\end{array}$ \\
\hline & & $\begin{array}{l}\text { Salmonella } \\
\text { arizonae(2) }\end{array}$ & $\begin{array}{c}32 / 512 \\
128 / 512\end{array}$ & $\begin{array}{l}\text { MEZ,AMP,CTX,E(1) } \\
\text { MEZ,AMP,PRL,E(1) }\end{array}$ & - & $\operatorname{tet}(\mathrm{E})$ \\
\hline & & \begin{tabular}{|l} 
Serratia \\
marcescens(3)
\end{tabular} & $\begin{array}{c}32 / 128 \\
256 / 512\end{array}$ & $\begin{array}{l}\text { MEZ,AMP,AMC,PRL,E,SXT,CIP(1) } \\
\text { E,CIP(2) }\end{array}$ & BMSF & $\begin{array}{l}\operatorname{tet}(\mathrm{A}), \operatorname{tet}(\mathrm{B}) \\
\text { nd }\end{array}$ \\
\hline & & $\begin{array}{l}\text { Vibrio } \\
\text { parahaemolyticus(2) }\end{array}$ & $32 / 128$ & $\begin{array}{l}\text { MEZ,AMP,PRL,CAZ,CTX(1) } \\
\text { MEZ,AMP,AMC,PRL,E,SXT,CIP(1) }\end{array}$ & BMSPF & $\operatorname{tet}(\mathrm{E})$ \\
\hline & & $\begin{array}{l}\text { Aeromonas } \\
\text { allosaccharophila(2) }\end{array}$ & $32 / 512$ & $\begin{array}{l}\text { MEZ,AMP,AMC,PRL,CTX,E,TGC,SXT,C(1) } \\
\text { MEZ,AMP,PRL,E,TGC,SXT(1) }\end{array}$ & $\begin{array}{l}\text { BMTSP } \\
\text { BMTS }\end{array}$ & $\operatorname{tet}(\mathrm{A})$ \\
\hline & & $\begin{array}{l}\text { Aeromonas } \\
\text { hydrophila(4) }\end{array}$ & $128 / 512$ & $\begin{array}{l}\text { AMP,E(1) } \\
\text { AMP,AMC,E(1) } \\
\text { AMP,AMC,E(1) } \\
\text { AMP,AMC,E(1) }\end{array}$ & - & $\begin{array}{l}\operatorname{tet}(\mathrm{A}) \\
\operatorname{tet}(\mathrm{A}) \\
\operatorname{tet}(\mathrm{B}) \\
\operatorname{tet}(\mathrm{E})\end{array}$ \\
\hline & & $\begin{array}{l}\text { Aeromonas } \\
\text { jandei }(1)\end{array}$ & $32 / 512$ & MEZ,AMP,AMC,PRL,CTX,E,TGC,C(1) & ВMTP & $\operatorname{tet}(\mathrm{A})$ \\
\hline & & $\begin{array}{l}\text { Aeromonas } \\
\text { sobria(4) }\end{array}$ & $128 / 512(4$ & MEZ,CAZ,CTX,CN,TOB,E,SXT,C,CIP(4) & BAMSPF(4) & $\operatorname{tet}(\mathrm{A})(2)$ \\
\hline & \multirow{7}{*}{\begin{tabular}{|c} 
OTC $^{\mathrm{R}}$ \\
\\
\end{tabular}} & $\begin{array}{l}\text { Citrobacter } \\
\text { freundii(1) }\end{array}$ & $128 / 256$ & MEZ,AMP,AMC,CAZ,CTX,E,SXT(1) & BMS & $\operatorname{tet}(\mathrm{A})$ \\
\hline & & $\begin{array}{l}\text { Flavimonas } \\
\text { oryzihabitans (1) }\end{array}$ & $128 / 128$ & PRL,CAZ,TOB,E(1) & BAM & $\operatorname{tet}(\mathrm{A})$ \\
\hline & & Pantoea spp.(1) & $96 / 128$ & MEZ,AMP,AMC,CAZ,CTX(1) & - & $\operatorname{tet}(\mathrm{D})$ \\
\hline & & $\begin{array}{l}\text { Pseudomonas } \\
\text { putida(1) }\end{array}$ & $128 / 512$ & AMP,AMC,CAZ,TOB,E,TGC,C(1) & BAMTP & $\operatorname{tet}(\mathrm{A})$ \\
\hline & & Salmonella spp.(2) & $32 / 96$ & MEZ,AMP,PRL,E,CIP(2) & BMF & $\operatorname{tet}(\mathrm{E})$ \\
\hline & & $\begin{array}{l}\text { Shewanella } \\
\text { putrefaciens(2) }\end{array}$ & $32 / 96$ & AMP,AMC,CAZ,E(2) & - & $\operatorname{tet}(\mathrm{A}), \operatorname{tet}(\mathrm{B}$ \\
\hline & & \begin{tabular}{|l|} 
Vibrio \\
metschnikovii(1)
\end{tabular} & $32 / 96$ & MEZ,AMP,PRL,CAZ,CTX(1) & - & $\operatorname{tet}(\mathrm{A})$ \\
\hline
\end{tabular}

In treated wastewater samples, $\mathrm{TET}^{\mathrm{R}}$ group isolates which were the least sensitive to the tested drugs were Vibrio parahaemoliticus, Klebsiella pneumoniae and Pasteurella pneumotropica (MIC of TET - $32 \mu \mathrm{g} / \mathrm{mL}$, MIC of OTC - 128 or $256 \mu \mathrm{g} / \mathrm{mL}$, resistant to four or five classes of antibiotics). In the $\mathrm{OTC}^{\mathrm{R}}$ group, the highest drug resistance was reported for Aeromonas sobria (MIC of TET - $128 \mu \mathrm{g} / \mathrm{mL}$, MIC of OTC $-512 \mu \mathrm{g} / \mathrm{mL}$, 
MDR to six classes of drugs). The isolates from treated wastewater were characterized by multiple drug resistance. In the $\mathrm{TET}^{\mathrm{R}}$ group $45 \%$ of isolates were multidrug resistant to three or four groups of antibiotics, in the $\mathrm{OTC}^{\mathrm{R}}$ group $60 \%$ isolates were multidrug bacteria (Table 2). Regardless of the sampling site, the MIC values of tetracycline were always lower than oxytetracycline MICs (Table 2). In both types of analyzed wastewater, tetracycline MICs were determined in the range of 32 to $256 \mu \mathrm{g} / \mathrm{mL}$. The MIC values of OTC ranged from 96 to $512 \mu \mathrm{g} / \mathrm{mL}$ in untreated sewage, and from 128 to $512 \mu \mathrm{g} / \mathrm{mL}$ in treated wastewater. In treated wastewater samples, the majority of $\mathrm{TET}^{\mathrm{R}}$ and $\mathrm{OTC}^{\mathrm{R}}$ isolates were characterized by the presence of the tet(A) gene which was noted in $60 \%$ strains. In the group of $\mathrm{TET}^{\mathrm{R}}$ strains showing the lowest levels of drug resistance, the presence of the tet(A) and tet(B)gene was noted (Vibrio parahaemoliticus and Klebsiella pneumoniae). In treated wastewater, $\mathrm{OTC}^{\mathrm{R}}$ strains of the genus Aeromonas featured $\operatorname{tet}(\mathrm{A}), \operatorname{tet}(\mathrm{B})$ and $\operatorname{tet}(\mathrm{E})$ genes (Table 2).

\section{Discussion}

The treatment process decreased $\mathrm{TET}^{\mathrm{R}}$ and $\mathrm{OTC}^{\mathrm{R}}$ bacterial counts by two orders of magnitude. The abundance of $\mathrm{OTC}^{\mathrm{R}}$ bacteria was somewhat higher in both untreated and treated wastewater samples. There is a general scarcity of data regarding the populations of wastewater-borne heterotrophic bacteria resistant to tetracycline and oxytetracycline. In studies of treated wastewater, Kim et al. [20] and Huang et al. [11] determined TET ${ }^{\mathrm{R}}$ counts in the range of $10^{2}-10^{3} \mathrm{CFU} / \mathrm{mL}$, and their findings are consistent with our results. Vast similarities are also observed in $\mathrm{TET}^{\mathrm{R}}$ bacteria's share of HPC which was determined at 0 to $2 \%$ by Kim et al. [20], Huang et al. [11] and Munir et al. [21] and at $1.61 \%$ in this study. It should be noted, however, that tetracycline concentrations reached $16 \mu \mathrm{g} / \mathrm{ml}$ in the experiment described by Huang et al. [11], compared with $32 \mu \mathrm{g} / \mathrm{mL}$ in a study by Kim et al. [20] and in the present study. Then, bacteria resistant to tetracyclines constitute a small part of HPC in treated wastewater - it may be due to of lack natural resiatance to tetracyclines among bacteria. $\mathrm{Tet}^{\mathrm{R}}$ isolates were not marked by a predominance of a single bacterial species or genus, whereas bacteria of the genus Aeromonas were the most abundant microorganisms in the group of $\mathrm{OTC}^{\mathrm{R}}$ isolates. Aeromonas bacteria are popularly observed in both untreated wastewater [22] and treated effluent from fish farms [23, 24]. Huys et al. [25] and Rhodes et al. [26] found more than $85 \%$ bacteria of the genus Aeromonas to be oxytetracycline-resistant. In this study, relatively large populations of Enterobacteriaceae microorganisms were reported in both, $\mathrm{TET}^{\mathrm{R}}$ and $\mathrm{OTC}^{\mathrm{R}}$ isolates, and similar observations were made by Guillaume et al. [27] and Moura et al. [28]. A comparison of MIC values and multiple drug resistance of the least resistant TET $^{\mathrm{R}}$ isolates in samples of untreated and treated wastewater indicates a drop in resistance to tetracycline, oxytetracycline and a decrease in multiple drug resistance as a result of sewage treatment. The reverse was observed in the $\mathrm{OTC}^{\mathrm{R}}$ group which resistance to tetracycline and oxytetracycline decreased with an increase in the number of multiple drug-resistant strains. In the $\mathrm{TET}^{\mathrm{R}}$ group, the majority of isolates obtained from untreated wastewater were resistant to four classes of antibiotics, whereas bacterial isolates from treated wastewater samples were resistant to one or two groups of antibiotics. The majority of OTC ${ }^{\mathrm{R}}$ bacteria identified in untreated wastewater were not multidrug resistant, however four isolates found in treated effluent samples were resistant to of all analyzed antibiotics. Our findings are consistent with the results of published studies [29]. The results of our previous study [30] and other authors' findings $[31,32]$ testify to the high drug resistance of $\mathrm{TET}^{\mathrm{R}}$ and $\mathrm{OTC}^{\mathrm{R}}$ bacteria. According to Hall et al. [33], resistance to a single antibiotic could lead to selective resistance to other drugs and, ultimately, multiple-drug resistance. In untreated wastewater isolates, there was not the predominant gene in the $\mathrm{TET}^{\mathrm{R}}$ group, $\operatorname{tet}(\mathrm{A})$ was 
most frequently determined in the $\mathrm{OTC}^{\mathrm{R}}$ groups, whereas the predominance of tet(A) gene was noted in both bacterial groups from treated effluent. Sandalli et al. [34] and Tao et al. [19] have demonstrated the predominance of the tet(A) gene in Enterobacteriaceae bacteria, and Harnisz et al. [14] - in bacteria of Aeromonas genus. The tet(A) gene, which encodes the removal of tetracyclines from the cell with the involvement of transport proteins, is often found on plasmids, including conjugating plasmids [35]. In this study, the high frequency of tet(A) noted in untreated and treated wastewater, could be attributed to the gene's presence on mobile plasmids. In the work of Guillaume et al. [27], tet(A) was found to be highly stable in Salmonella sp. isolated from treated wastewater. The presence of $\operatorname{tet}(\mathrm{B}), \operatorname{tet}(\mathrm{E})$ and, rarely, $\operatorname{tet}(\mathrm{D})$ determinants has also been noted in $\mathrm{TET}^{\mathrm{R}}$ and $\mathrm{OTC}^{\mathrm{R}}$ isolates, whereas the tet $(\mathrm{C})$ gene was not found. Similar results were reported by Börjesson et al. [36], Sandalli et al. [34] and Tao et al. [19]. Auerbach et al. [37] observed a wide variety of tetracycline resistance genes in wastewater, including tet $(\mathrm{C})$ which was not identified in this study. The above could attest to the "regional" occurrence of tetracycline resistance determinants, subject to the climate, the intestinal microbiota of the local population and various antibiotic treatments. In this experiment, the simultaneous presence of two resistance determinants, tet(A) and tet(B), was noted only in two strains of the family Enterobacteriaceae: Serratia marcescens and Shewanella putrefaciens and three isolates of genus Acinteobacter and Aeromonas. According to Tao et al. [19], around 30\% bacteria have at least two genes encoding tetracycline resistance. Similar findings were reported in studies of other bacterial species by Akinbowale et al. [15], Henriques et al. [31] and Nikolakopoulou et al. [32].

\section{Conslusions}

Based on the results of this study, it can be concluded that the drug resistance of TET ${ }^{\mathrm{R}}$ bacteria was attenuated and the drug resistance of $\mathrm{OTC}^{\mathrm{R}}$ bacteria was amplified in the course of the treatment processes. In both bacterial groups, the frequency of the tet(A) gene was high in untreated and treated wastewater. Our results also indicate that treated wastewater is a reservoir of multiple drug-resistant bacteria as well as resistance determinants which may pose a health hazard for humans and animals when released to the natural environment.

\section{References}

1. F. Baquero, J.L. Martinez, R. Canton, Curr. Opin. Biotech. 19, 260-265 (2008)

2. J. Williams-Nguyen, J.B. Sallach, S. Bartelt-Hunt, A.B. Boxall, L.M. Durso, J.E. McLain, R.S. Singer, D.D. Snow, J.L. Zilles, J. Environ. Qual. 45, 394-406 (2016)

3. K.S. Le Corre, C. Ort, D. Kateley, B. Allen, B.I. Escher, J. Keller, Environ. Int. 45, 99-111 (2012)

4. L. Boto, Proc. R. Soc. B. 277, 819-827 (2010)

5. Clinical and Laboratory Standards Institute, Performance standards for susceptibility testing, M100-S15. CLSI, Wayne, Pennsylvania, USA (2005)

6. E. Korzeniewska, M. Harnisz, J. Environ. Manage. 128, 904-911 (2013)

7. M.L. Luprano, M. De Sanctis, G. Del Moro, C. Di Iaconi, A. Lopez, C. Levantesi, Sci. Total Environ. 571, 809-818 (2016)

8. A. Schlüter, R. Szczepanowski, A. Pühler, FEMS Microbiol. Rev. 31, 449-477 (2007)

9. R. Szczepanowski, B. Linke, I. Krahn, Microbiol. 155, 7, 2306-2319 (2009) 
10. A. Osińska, M. Harnisz, E. Korzeniewska, Environ. Sci. Pollut. Res. 23, 10818-10831 (2016)

11. J.J. Huang, H.Y. Hu, S.Q. Lu, Y. Li, F. Tang, Y. Lu, B. Wei, Environ. Int. 42, 31-36 (2011)

12. A. Osińska, E. Korzeniewska, M. Harnisz, S. Niestępski, Sci. Total Environ. 577, 367-375 (2017)

13. M.N. Nielsen, A. Winding, Technical Report 388, National Environmental Research Institute, Denmark (2002)

14. M. Harnisz, E. Korzeniewska, S. Ciesielski, I. Gołaś, Sci. Total Environ. 505, 704-711 (2015)

15. A.L. Akinbowale, H. Peng, M.D. Barton, J. Appl. Microbiol. 100, 1103-1113 (2006)

16. Clinical and Laboratory Standards Institute (CLSI). Performance standards for susceptibility testing, M100-S15. Wayne, Pennsylvania, USA (2014)

17. Chopra, M. Roberts, Microbiol. Mol. Biol. R. 65, 232-260 (2001)

18. M. Nawaz, K. Sung, S.A. Khan, A.A. Khan, R. Steele, Appl. Environ. Microbiol. 72, 6461-6466 (2006)

19. R. Tao, G.G. Ying, H.C. Su, H.W. Zhou, J.P.S Sidhu, Environ. Pollut. 158, 2101-2109 (2010)

20. S. Kim, H. Park, K. Chandran, Chemosphere 78, 1071-1077 (2010)

21. M. Munir, K. Wong, I. Xagoraraki, Water Res. 45, 681-693 (2011)

22. V. Figueira, I. Vaz-Moreira, M. Silva, C.M. Manaia, Water Res. 45, 5599-5611 (2011)

23. M. Harnisz, S. Tucholski, Ecol. Eng. 36, 4, 466-470 (2010)

24. M. Harnisz, E. Korzeniewska, I. Gołaś, Chemosphere 128, 134-141 (2015)

25. G. Huys, D. Gevers, R. Temmerman, M. Cnockaert, R. Denys, G. Rhodes, R. Pickup, P. McGann , M. Hiney, P. Smith, J. Swings, J. Syst. Appl. Microbiol. 24, 1, 122-130 (2001)

26. G. Rhodes, G. Huys, J. Swings, P. McGann, M. Hiney, P. Smith, J. Swings, Appl. Environ. Microbiol. 66, 3883-3890 (2000)

27. G. Guillaume, D. Verbrugge, M.L. Chasseur-Libotte, W. Moens, J.M. Collard, FEMS Microbiol. Ecol. 32, 77-85 (2000)

28. A. Moura, I. Henriques, R. Ribeiro, A. Correia, J. Antimicrob. Chemoth. 60, $1243-1250$ (2007)

29. Y. Zhang, C.F. Marrs, C. Simon, C. Xi, Sci. Total Environ. 407, 3702-3706 (2009)

30. M. Harnisz, I. Gołaś, M. Pietruk, Ecol. Indic. 11, 663-668 (2011)

31. I.S. Henriques, F. Fonseca, A. Alves, M.J. Saavedra, A. Correia, Lett. Appl. Microbiol. 47, 526-533 (2008)

32. T.L. Nikolakopoulou, E.P. Giannoutsou, A.A. Karabatsou, A.D. Karagouni, J. Microbiol. 46, 633-640 (2008)

33. A.R. Hall, D.C. Angst, K.T. Schiessl, M. Ackermann, Evol. Appl. 8, 261-272 (2015)

34. C. Sandalli, O.B. Ozgumus, A. Sevim, World J. Microbiol. Biot. 26, 2099-2103 (2010)

35. A.S. Schmidt, M.S. Bruun, I. Dalsgaard, J.L. Larsen, Appl. Environ. Microb. 67, 5675-5682 (2001)

36. S. Börjesson, A. Mattsson, P.E. Lindgren, J. Water Health 8, 2, 247-256 (2010)

37. E.A. Auerbach, E.E. Seyfried, K.D. McMahon, Water Res. 41, 5, 1143-1151 (2007) 